\title{
How to obtain and maintain favorable results after heart transplantation: keys to success?
}

\author{
Johan J. A. Van Cleemput ${ }^{1}$, Tom O. M. Verbelen ${ }^{2}$, Lucas N. L. Van Aelst ${ }^{1}$, Filip R. L. Rega ${ }^{2}$ \\ ${ }^{1}$ Department of Cardiology, ${ }^{2}$ Department of Cardiac Surgery, University Hospital Leuven, Leuven, Belgium \\ Correspondence to: Johan J. A. Van Cleemput. Department of Cardiology, University Hospital Leuven, Herestraat 49, B-3000 Leuven, Belgium. \\ Email: johan.vancleemput@uzleuven.be.
}

\begin{abstract}
We compared survival in our heart recipients with survival rates reported by the International Society of Heart and Lung Transplantation (ISHLT) Registry. As recipient and donor characteristics are changing over time, we studied four different eras. In order to differentiate between short- and long-term survival, we analyzed both overall survival and survival at one year. Obviously, this exercise is only relevant when baseline donor and recipient characteristics are comparable, as these differences may affect the outcome in opposite directions. To overcome this potential bias as much as possible, we calculated the Index for Mortality Prediction After Cardiac Transplantation (IMPACT)-scores and the Donor Risk Index (DRI). Looking to our results, we found that our DRIs in the different eras are almost equal to those obtained from the United Network for Organ Sharing database in the very same eras. Our IMPACT-scores, on the other hand, seem higher than those reported by ISHLT. Survival after transplantation and conditional on 1-year survival was higher than the outcome reported by the ISHLT Registry. As our operation technique and post-transplant immunosuppressive schedule did not differ from most centers, we speculated on potential factors that might contribute to our positive results. Patient selection and a relatively short waiting time are important contributors to the overall survival benefit. Our centralized follow-up may also have played an important role. Finally, the indefinite compulsory health insurance coverage in our country and easy access to different screening programs might also have influenced our outcome in a positive way. We are well aware that with challenges like donor organ shortage, more and more patients on mechanical circulatory support (MCS) will affect outcomes in the future.
\end{abstract}

Keywords: Heart transplantation; predictors; survival

Submitted Sep 11, 2017. Accepted for publication Nov 25, 2017.

doi: $10.21037 /$ acs.2017.12.03

View this article at: http://dx.doi.org/10.21037/acs.2017.12.03

\section{Introduction}

Comparing the results of hip surgery performed by one surgeon with the results of his colleague working in the hospital next door, is asking for trouble. Comparing results of one heart transplant center with those of another or, even more challenging, those of a registry, is at least as daunting.

Nevertheless, it is worthwhile to critically review one's results and compare them with those of peers. In case they differ manifestly, one has to speculate on why this is the case considering the importance our society currently attributes to cost effectiveness and transparency. Of course, this exercise only makes sense when you are comparing apples with apples. You should first examine that you are transplanting the same types of patients and that you are using the same types of donors.

We compared our short- and long-term survival data with those of the ISHLT registry. To do so, we also compared our recipient and donor risk profiles with those of the UNOS database. Finally, we speculated on contributing factors that affected our outcome.

\section{Patients and methods}

We compared baseline characteristics of heart recipients 
transplanted in the University hospital of Leuven (Leuven) between September 1987 and December 2015, with those of recipients reported to the International Society of Heart and Lung Transplantation (ISHLT) and transplanted in the same period. As baseline characteristics changed over time, we analyzed four different eras: 1987-1991, 1992-2001, 2002-2008 and 2009-2015. Data were derived from our own database and from the 2009 (1992-2001 and 20022008) and 2016 (2009-2015) ISHLT Registries (1,2). In the Leuven cohort, ANOVA was used to compare differences between groups. Tests for trend over time were performed with the actual year of transplantation, using a Spearman correlation for continuous variables, a Kruskal Wallis test for categorical data and a Cochran-Armitage trend test for ordinal or binary variables. Baseline characteristics of the Leuven cohort and the ISHLT Registries were compared with a two-sided z-test or a Chi-Square test as appropriate. As we had no access to sufficient ISHLT data for the era between 1987 and 1991, comparisons are only made for the 3 last eras.

To estimate the risk profile of our donors, we calculated the average Donor Risk Index (DRI) for transplantations performed between 1-2-1996 and 0108-2010 and compared them with the DRI derived from the independently validated United Network for Organ Sharing (UNOS) database of donors (3). The DRI incorporates 4 donor and procedure variables (donor age and blood urea nitrogen ratio, race mismatch and ischemic time) and predicts 30-day, 1 - and 5-year post-transplant mortality (3). For the recipient risk profile, we measured the individual Index for Mortality Prediction After Cardiac Transplantation (IMPACT)-scores in corresponding eras. This allowed us to match these data with two published cohorts namely one derived from a UNOS database from which the IMPACT-score was originally derived and validated and one from an ISHLT database that validated the United-States derived IMPACT-score using international data $(4,5)$. The IMPACT score relies on preoperative recipient characteristics and predicts short- and long-term survival after heart transplantation (4).

As we only had access to individual data from our own database, a 2-sided Z-test was used to compare our DRI and IMPACT-scores with those of the registries. The individual characteristics used to calculate the DRI and the IMPACTscore, were compared between the Leuven and the other cohorts with a 2 -sided Z-test and a Chi-Square test, when available in the original publications.

In the survival analyses, recipients were censored when re-transplanted. We compared the Leuven and ISHLT results for the total cohort and for recipients transplanted in the 4 different eras. To better distinguish between early and late differences in survival, we repeated the analyses for survival at one year. A Log-rank test was used to compare differences in survival between the different era's in the Leuven group.

Differences in survival between the Leuven and ISHLT cohorts were compared with a Chi-Square test for each individual postoperative year. Statistical analyses are performed with SAS 9.4 (SAS Institute, Cary, NC, USA).

\section{Results}

\section{Baseline characteristics}

The Leuven heart transplant program started in September 1987. Until the end of 2015, 648 transplantations were performed in 615 patients, resulting in an average annual transplantation rate of 23 (range, 15-33). Thirty recipients received a second donor heart and one patient was transplanted three times. Ten patients were re-transplanted for primary graft failure within the first post-operative week. The other re-transplantations were performed because of acute $(n=7)$ or chronic $(n=14)$ late graft failure after 9 (range, $0.5-22$ ) years on average. Three recipients underwent a combined heart-liver and 23 a heart-kidney transplantation. No patient was lost to follow-up.

The average recipient age at transplantation was $49 \pm 14$ (range, 3-70) years and 126 (19\%) were women. The most frequent indications for transplantation were ischemic heart disease (42\%), cardiomyopathy (40\%, mainly dilated cardiomyopathy), valvular (5\%) and congenital (5\%) heart disease.

Patients were transplanted after $123 \pm 115$ days (range, 0-566 days) on the waiting list. Eleven percent were transplanted from the high urgency (HU) list and had to wait $11 \pm 20$ (range, $1-117$ ) days.

The mean donor age was $34 \pm 13$ (range, $1-66$ ) years and $70 \%$ of the donors were men.

\section{Treatment and follow-up}

Initially all transplantations were performed using the Shumway bi-atrial technique. Since 2009 this technique was converted to a bi-caval anastomosis. All recipients receive induction therapy with anti-thymocyte globulin (rATG). Maintenance immunosuppression changed over 
time. Initially, patients were treated with cyclosporine A, azathioprine and steroids. Since 2000 tacrolimus became the standard calcineurin inhibitor (CNI), mycophenolate mofetil replaced azathioprine and most patients went off steroids after the first year. Everolimus is occasionally used in combination with a reduced dose of tacrolimus in patients with graft vasculopathy or with renal failure.

All recipients receive prophylaxis against pneumocystis jiroveci pneumonia for 6 months and $C M V$-negative recipients with a $\mathrm{CMV}$-positive donor are treated with ganciclovir and anti-CMV globulins for 3 months. Statins are given unless contra-indicated. Antiplatelet agents are only initiated in case of new atherothrombotic events.

All follow-up is centralized to one center. Around 15 per protocol endomyocardial biopsies are performed in the first postoperative year or on indication, thereafter.

CNI through levels are checked monthly. Every 3 months, recipients have an out-patient visit and are seen by a specialized transplant nurse and a transplant cardiologist. At follow-up, they have a more extensive blood test, an electrocardiogram, an X-ray of the chest and a cardiac ultrasound. Every year there is a comprehensive check-up including a right heart catheterization. After 1, 2, 3, 5 years and every 5 years thereafter, or on clinical indication, a coronary angiography is performed. In case of medical problems, a 24/7 helpline is available. All major non-cardiac health problems are preferentially referred to treatment in our hospital.

\section{Comparability of donors and recipients}

Recipient and donor characteristics of the Leuven transplant program that affected short- and long-term post-transplant survival in different studies and registries are summarized in Table 1. Comparable data for heart recipients reported to the ISHLT are shown in the Supplementary (Table S1).

Over time similar changes are seen in the Leuven and ISHLT cohorts. For the recipients, there is a decrease in male preponderance and in patients with ischemic heart disease, and fewer recipients are hospitalized at the moment of transplantation. In both groups, the percentage of patients on mechanical circulatory support (MCS) increases rapidly. As for the donors, we see an increasing donor age and longer ischemic times (Figure 1). In the Leuven group, there is also an increase in waiting time (Figure 1).

Despite resemblances in trends, important differences remain between the Leuven and the ISHLT cohorts that might result in different transplant risks. Due to insufficient data for the era between 1987 and 1991, comparisons are only made for the 3 last eras (Table S1).

Some factors might disproportionately increase the risk of the ISHLT group, for example, the higher proportion of hospitalized patients and patients on inotropes, or the use of an intra-aortic balloon pump (all eras). Furthermore, ISHLT recipients were older and had twice as much diabetes ( 2 most recent eras). The risk of our recipients increased due to older donor age ( 2 most recent eras) and longer ischemic times (second and third era). On top of that, we had more patients that underwent previous cardiac surgery, more re-transplantations and more patients with congenital heart disease (all eras) or valvular heart disease (second and third era). All these factors might negatively impact our results.

Obviously, these numbers only provide an indication of the expected risk and can by no means lead to the conclusion that we transplant higher risk recipients with higher risk donors. In order to better quantify our donor and recipient risk, we calculated our DRI and IMPACTscores.

As shown in Table 2, the DRI of our group is almost numerically identical to the DRIs in the derivation and validation cohorts from the UNOS database. Most probably a slightly shorter ischemic time neutralized our manifestly higher donor age. As for the IMPACTscores, no difference was found with those obtained from the UNOS database (Table 3). The IMPACT-score in the ISHLT publication was significantly lower, suggesting a lower risk profile of their recipients (Table 4). Behind the composite scores, we see again significant differences in contributing factors. The protective effect of our younger recipients with less diabetes might be leveled out by the fact that we have fewer patients with an idiopathic cardiomyopathy, more with congenital heart disease and more on mechanical ventilation, temporary circulatory support and late VAD's.

\section{Survival}

Survival of our recipients is compared with survival of all patients reported to the ISHLT registry for the entire cohort (Figure $2 A$ ) and for the recipients transplanted in 4 different eras (Figure 2B). Except for the follow-up beyond 14 years of recipients transplanted in the first era, our results are above the average of the Registry (Tables $S 2$ $S 7)$. In Figure $3 A, B$, survival curves are shown conditional on survival to 1 year. The fact that the differences in 


\begin{tabular}{|c|c|c|c|c|c|c|}
\hline Era & 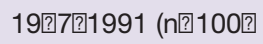 & 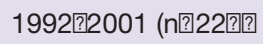 & 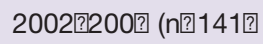 & 2009?2014圆n?179? & Pףalue & Pףalue (trend? \\
\hline 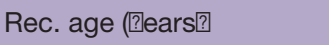 & 51 圆 12 & 51 圆 13 & 4젬ำ16 & 4메문 & NS & NS \\
\hline 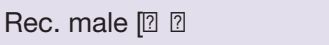 & 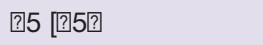 & 1?3त्वृ?]0? & 112通79? & 132迎74? & NS & ?20.05 \\
\hline Rec.ఇweight很g?? & 6제? 12 & 70유 13 & 71圆16 & 74圆1圆 & ? 0.01 & ? 0.001 \\
\hline Rec.Theight政的? & 171圆9 & 171司9 & 172??12 & 172? 14 & NS & NS \\
\hline 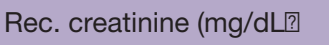 & 1.4 目 0.4 & 1.5?0.6 & 1.4 ? 0.6 & 1.3 ?우 0.6 & ? 0.01 & ? 0.01 \\
\hline Rec.ædiabetesत्रा]? ? & 9त्वृ9? & 22त्र|10? & 14제10ㅇ? & 1지젝10? & NS & NS \\
\hline 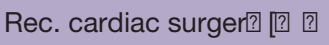 & 31乐31의 & 96재42? & 76团54문 & 119不66? & ? 0.001 & ?0.0001 \\
\hline 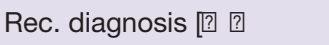 & & & & & ? 0.01 & ? 0.0001 \\
\hline Ischemic XMP & 52त्व|52? & 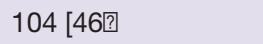 & 53त्वृ3?? & 61国34? & & \\
\hline Idiopathic & 34재]34? & 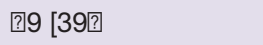 & 5제제41주 & 7뮈제44ㄴ? & & \\
\hline Valvularख̃P & 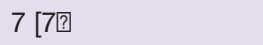 & 13䊈6? & 9त्वृ6? & 3त्वृ2? & & \\
\hline Re-transplantation & 3त्व[3] & 11园5? & 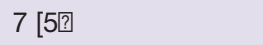 & 12迎7? & & \\
\hline Congenital & 2त्वृ2? & ?진? & 10젹7? & 13更7? & & \\
\hline ? ther? & 2雨2? & 3त्वा1? & 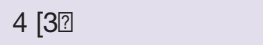 & 12园7司 & & \\
\hline 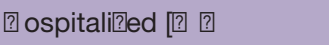 & 36团36? & 61国27? & 39त्रा2?? & 40东22? & NS & ? 0.05 \\
\hline 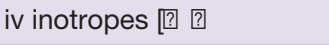 & 9囵9? & 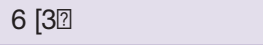 & 12迎9? & 7圆4ㅁ?ㅁ & ?20.05 & NS \\
\hline 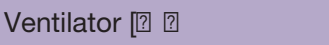 & 1圆1圆 & 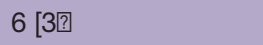 & 2त्र|1? & 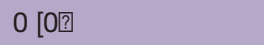 & NS? & NS? \\
\hline iABPत्रा?? ? & 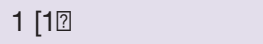 & 0त्वृ0? & 0त्वृ0? & Oत्व्या0? & NS? & NS? \\
\hline 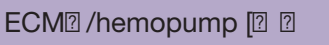 & 1圆1? & Oत्वृ0? & 1圆1圆 & 3त्वा2? & NS & ? 0.05 \\
\hline LVAD可?] ? & 2黾1司 & 15圂7?] & 33त्प्प23? & 71圆40? & ? 0.001 & ? 0.0001 \\
\hline RVAD元[?] [? & 3त्वा3? & 11园5? & 4[]ㅈ? & 5雨3궁 & NS & NS? \\
\hline TA? 迎[? ? & 0 & 0 & 0 & 0 & & \\
\hline 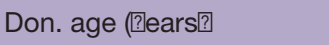 & 27?9 9 & 33ㄱ? 12 & 36 ? 14 & 39 ? 14 & ? 0.001 & ?0.0001 \\
\hline Don.ఇweight秋g? & 71 12 & 72? 12 & 73? 14 & 76? 10? & 20.01 & ? 0.01 \\
\hline Don.Theight㲎cm? & 176? 10 & 174ㅁำ10 & 174ㅁ? 12 & 174? 15 & NS? & NS? \\
\hline Don.?male这? [? & 76제76? & 15주졈69? & 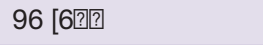 & 121圆6??? & NS & NS \\
\hline 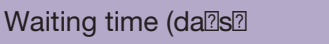 & 60?60 & 9지궁 95 & 115ㅇ?93 & 197누139 & ? 0.001 & ? 0.0001 \\
\hline 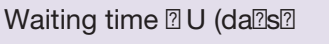 & NA & 4? 4 & 13ㅁ? 21 & 12?21 & NS & NS \\
\hline 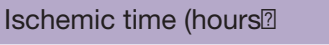 & 2.2? 0.7 & $2.6 ? 0.7$ & 3.0ำ 0.7 & 3.2?0.7 & ? 0.001 & ? 0.0001 \\
\hline ? LA?mismatches 제] ?? & & & & & ?20.05 & NS \\
\hline 0?2 & 9त्व[9? & 10쥬4ㄴ? & 6]14의 & 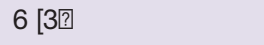 & & \\
\hline 3?ㄴ?? & 46]्व[46? & 71国31? & 49秂35? & 60西34? & & \\
\hline 5 ?6 & 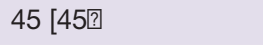 & 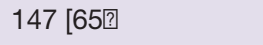 & ?6团61? & 113可63? & & \\
\hline 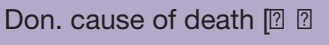 & & & & & ? 0.001 & ?0.0001 \\
\hline ? ead?trauma & 73त्वा73의 & 135졈59? & 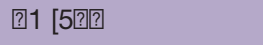 & 77圆43음 & & \\
\hline Stroke & 23त्र्प23? & 6?지지으 & 42雨30? & 73재441? & & \\
\hline ? ther & 4西4? & 25]्त्]11? & 1?]त्रा3? & 29त्र्[16? & & \\
\hline 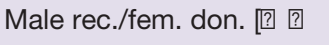 & 19त्]ा19? & 49त्वृ21? & 27त्र्प19? & 22त्र्प12? & NS & NS \\
\hline 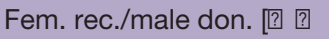 & 10त्व]10? & 23त्वृ10? & 10त्वi17? & 10需6? & NS & NS \\
\hline
\end{tabular}

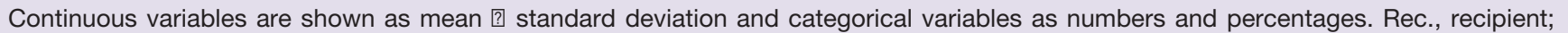

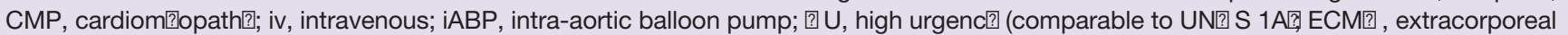

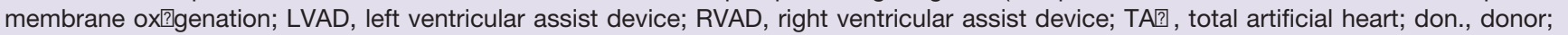

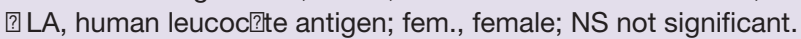


survival remain significant in this analysis suggests that our better long-term survival is not merely due to a lower 1-year mortality (Table S3). Seemingly, we also succeed in making a difference during the late follow-up.

\section{Mortality}

Two hundred and forty-four (40\%) recipients died during follow-up until the end of 2016 (Table 5). Not surprisingly both cardiovascular causes and malignancies account for more than $1 / 3$ of deaths. Malignancies, especially lung carcinomas, play an important role. Concerning cardiovascular causes of death, many recipients die suddenly. As graft vasculopathy had been demonstrated in many recipients before their sudden death, we believe that most of the sudden deaths were due to coronary artery disease. However late acute rejection cannot be excluded.

\section{Limitations}

Our study has several limitations. The most important being that it is impossible to prove that our baseline predicted risk doesn't differ from ISHLT. A case-control study matching for baseline characteristics was not feasible as we did not

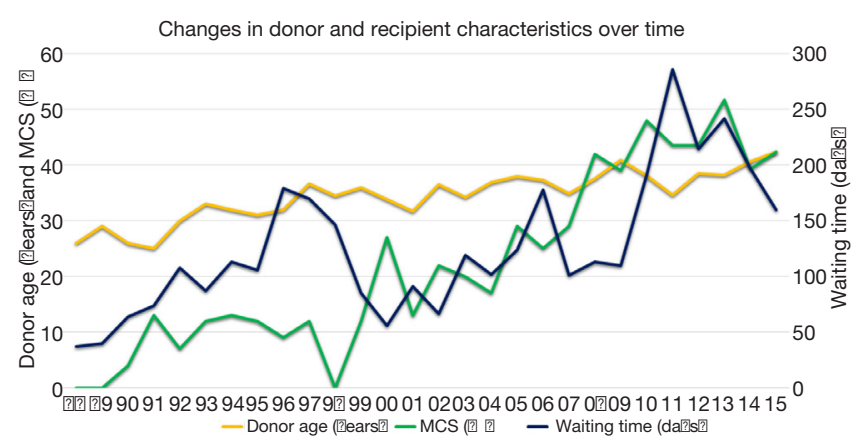

Figure 1 Changes in recipient and donor characteristics over time (Leuven). have access to the individual recipient and donor data from the ISHLT Registry. For the same reason, we could not perform a Cox proportional hazard regression analysis, using center as an independent variable. Potentially, important risk factors such as waiting time could not be imputed as they were not available in the Registries, nor in the seminal papers on the DRI and IMPACT-scores. Finally, we used data from the voluntary ISHLT Registry and the mandatory UNOS-database. Both depend on center reporting accuracy and completeness.

\section{Discussion}

We showed that both our short- and long-term survival are above the average reported by ISHLT. Despite the many differences in baseline recipient and donor characteristics between our group and the ISHLT cohorts, the remarkable similarities between our IMPACT-score and DRI and those reported in the literature strengthen our assumption that the difference in survival is not merely due to a lower risk profile of our donors or recipients. As we use standard operative techniques and immunosuppressive schedules, other factors have to be involved. In the absence of randomized clinical trials, we can only speculate which might play a role.

We focus on four different time intervals: the pretransplant period, the transplantation, the first year after transplantation and the long-term follow-up.

We are convinced that the importance of patient selection cannot be overestimated. The first hurdle in this process is to translate the indications and contraindications, described in the guidelines, to the individual patient $(6,7)$. As confidence may grow with experience and as several absolute contra-indications of the original guidelines have metamorphosed into relative contraindications, there is an inherent risk of progressively raising the bar, finally transplanting recipients with an unacceptably

\begin{tabular}{|c|c|c|c|c|c|}
\hline \multirow{2}{*}{ Cohort } & \multicolumn{2}{|l|}{ UN? S } & \multirow{2}{*}{ 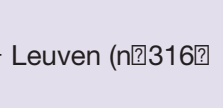 } & \multicolumn{2}{|l|}{ Pףalue } \\
\hline & Derivation通? 17,7? ?]?] & Validation活国 4,464? & & Leuven®s. @derivation & 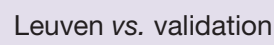 \\
\hline DRI-score & 4.0?‥1무 & 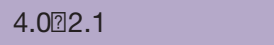 & 4.0?ㄱ.? & NS & NS \\
\hline 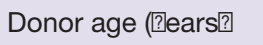 & 31.3?]12.6 & NA & 36.0? 13.7 & ??0.0001 & ? \\
\hline
\end{tabular}




\begin{tabular}{|c|c|c|c|c|c|}
\hline Cohort & Derivation[1]n? 17,079? & 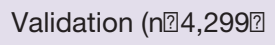 & 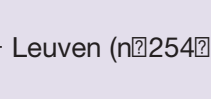 & 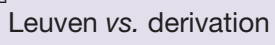 & 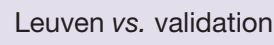 \\
\hline IMPACT-score & 6.1 ?3.7 & 6.1?3.7? & 6.2 ??? 5.2 & NS & NS \\
\hline Recipient旅ge开l?ears? & 52.1 111.9 & 51.?ำ? 12.1 & 49.ㅈ?구 14.9 & ?0.05 & ?20.05 \\
\hline \multicolumn{6}{|l|}{ 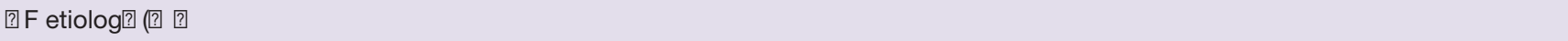 } \\
\hline Ischemic $\mathbb{C M P}$ & ?,11?]园47.1? & 2,024[4] $47.1 ?$ & 10제진 42.5? & NS & NS \\
\hline Idiopathic & 7,050凰42.10 & 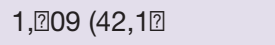 & 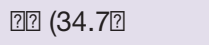 & ?ㅇ.05 & ?20.05 \\
\hline Congenital & 400园2.3? & 106政2.5? & 13园5.10 & ? 0.005 & 0.01 \\
\hline Clearance $2 / \mathrm{mL} / \mathrm{min}$, Cockroft? & 66.3?25.? & 66.0 ㅁ?25.6 & 64.1 回27.1 & NS & NS \\
\hline 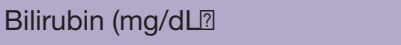 & 1.24 ?⒉11 & 1.31 国.27 & 1.06 ? 1.67 & NS & 20.05 \\
\hline 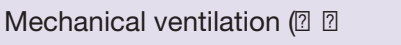 & 456和2.7? & 10제죽2.5? & 21죽.2? & ?0.0001 & ?0.0001 \\
\hline temp.民irculator? & 240凰1.4? & 46图1.10 & 23橾9.1? & ? 0.0001 & ? 0.0001 \\
\hline iABP这? ? & 927国5.4? & 220圂5.1圆 & 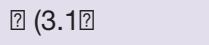 & NS & NS \\
\hline \multicolumn{6}{|l|}{ 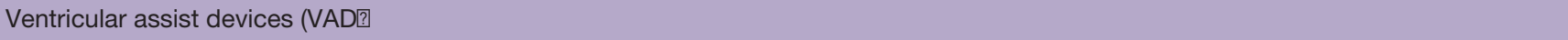 } \\
\hline 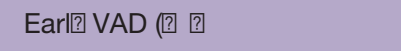 & 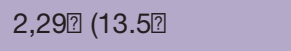 & 5目6圆13.6目 & 11圆4.3묵 & ? 0.0001 & ?0.0001 \\
\hline 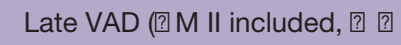 & 374行2.2? & ?7722.0? & 1지죽.1? & ?0.0001 & ?0.0001 \\
\hline
\end{tabular}

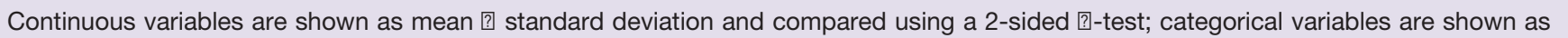

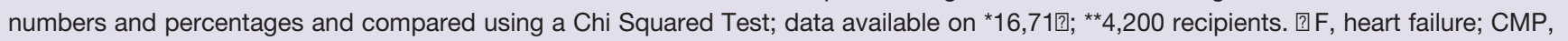
cardiom[?

high risk. For several of these patients, transplantation might indeed be the better option, but wasting an organ in an era of scarcity will automatically affect survival of other candidates on the waiting list. As the final decision to list can be cumbersome in particular patients, we always discuss high risk candidates on a formal monthly meeting (ad hoc, in case of urgency) with all transplant cardiologists, at least one cardiac surgeon and other (para-)medical specialists when applicable (psychologist, pediatrician, oncologist, pulmonologist, nephrologist, ...). Even when we realize that transplantation might be the better option for an individual patient, we will not list him, when the risk is considered unacceptably high. Using this strategy of consensus, a motivated and well-communicated negative advice is rarely questioned by the patient, his family or the referring physician.

When the patient is considered a potential candidate by the transplant team, a second crucial step is to obtain informed consent. Explaining the operative risk and the first-year results is not sufficient. Time should be taken to describe the long-term results, including the limitations and potential complications, in order to protect the candidate recipient against unrealistic expectations. Although often sobering, we believe that the median survival should be mentioned. It is a simple figure that helps the patient and his family to realize that even a successful transplantation is no guarantee for a normal lifespan. Only after understanding the complex consequences of a heart transplantation, the candidate can make a motivated choice.

In an era where many patients are referred for screening, after they received a long-term MCS in critical circumstances, it becomes more challenging to maintain this conservative policy and many patients that would 


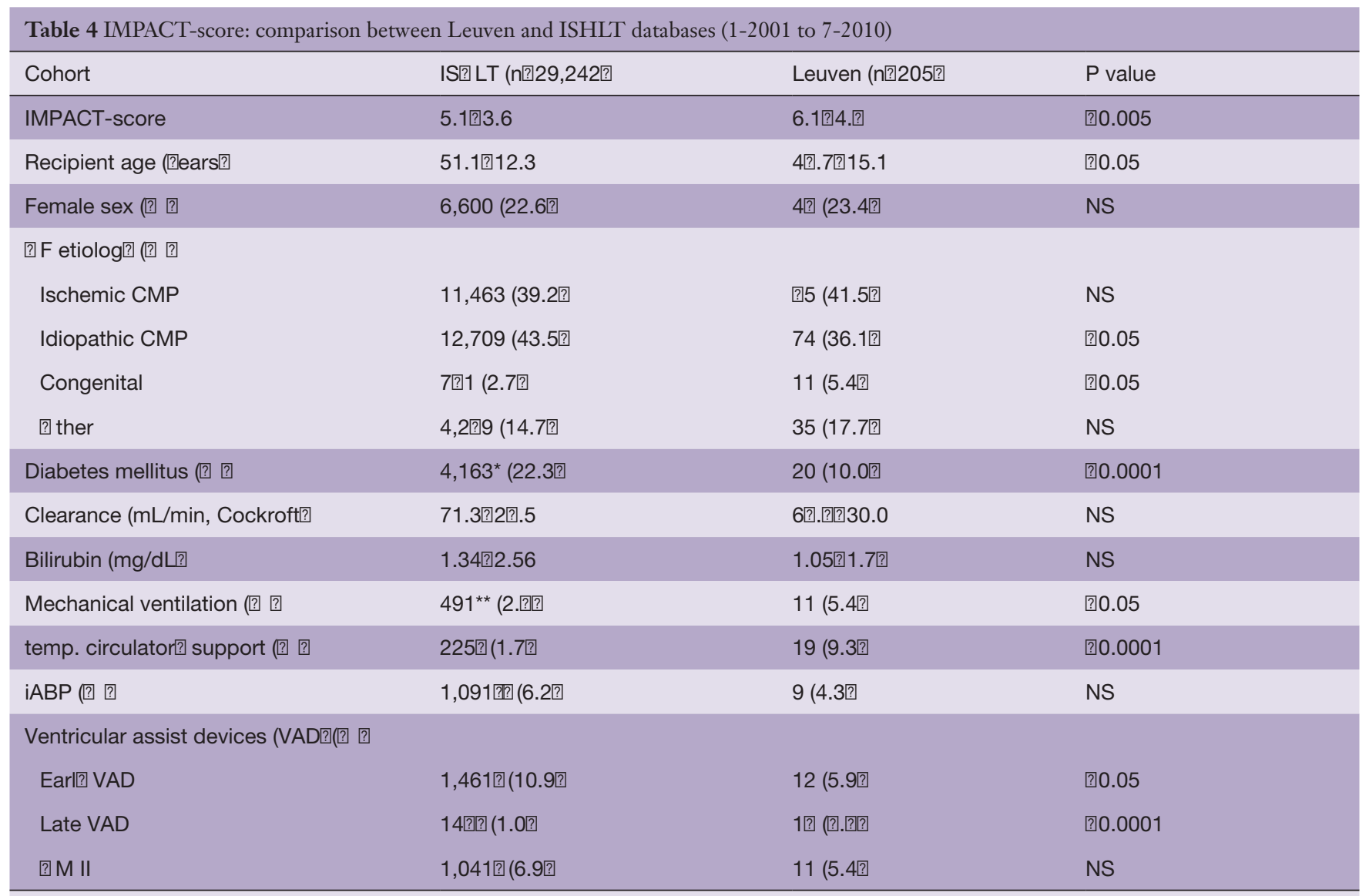

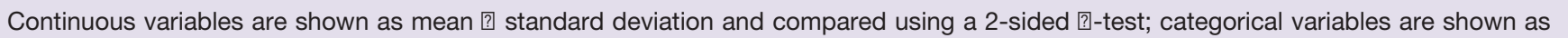

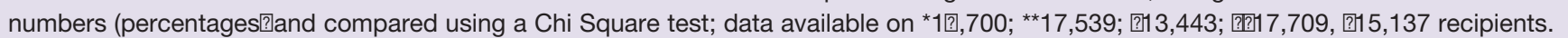

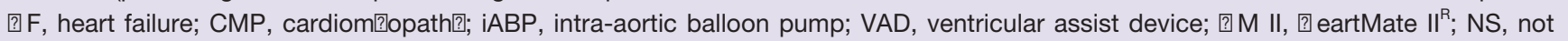
significant.
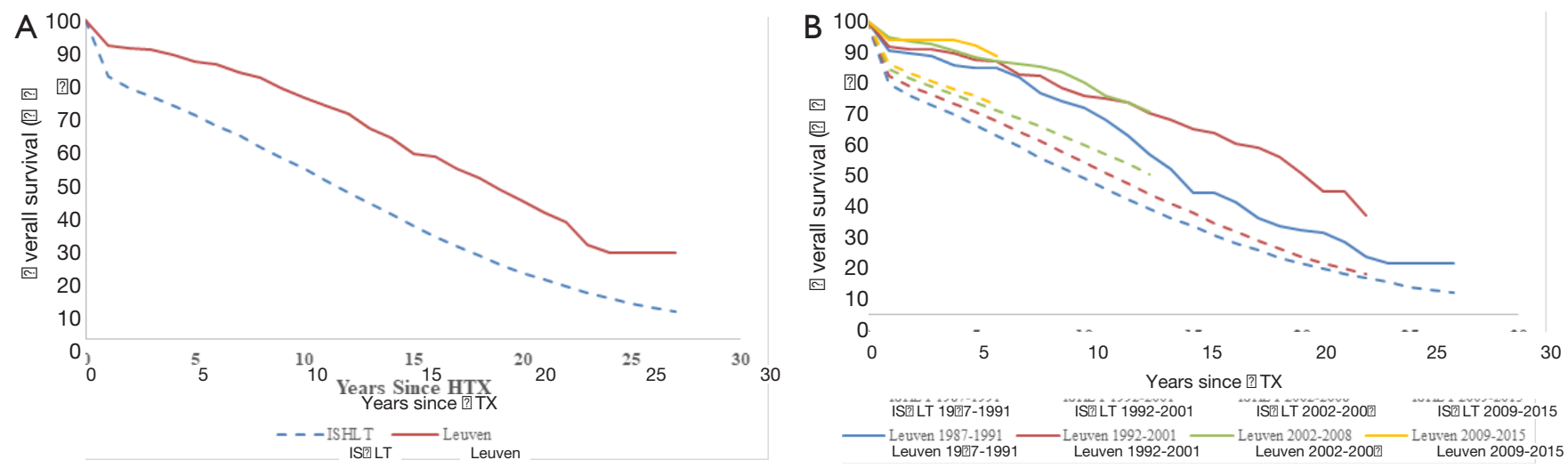

Figure 2 Survival of heart transplant recipients reported to ISHLT (from 1-1-1987 to 6-30-2015) and recipients transplanted in Leuven (from 9-1-1987 to 31-12-2015). (A) All recipients. Leuven ( $\mathrm{n}=648$ ) versus ISHLT ( $\mathrm{n}=109,423) \mathrm{P}<0.0001$ up to 27 years; (B) recipients by era: 1987-1991 ( $\mathrm{n}=100)$ and $(\mathrm{n}=17,173) \mathrm{P}<0.05$ up to 22 years; 1992-2001 ( $\mathrm{n}=228)$ and $(\mathrm{n}=40,019) \mathrm{P}<0.01$ up to 23 years; $2002-2008$ ( $\mathrm{n}=141)$ and ( $\mathrm{n}=26,044) \mathrm{P}<0.001$ up to 13 years; 2009-2015 ( $\mathrm{n}=179)$ and $(\mathrm{n}=26,187) \mathrm{P}<0.001$ up to 6 years. Chi Squared tests for differences in survival between Leuven and ISHLT per year. Log-rank test for survival in different eras in Leuven $\mathrm{P}<0.01$. 

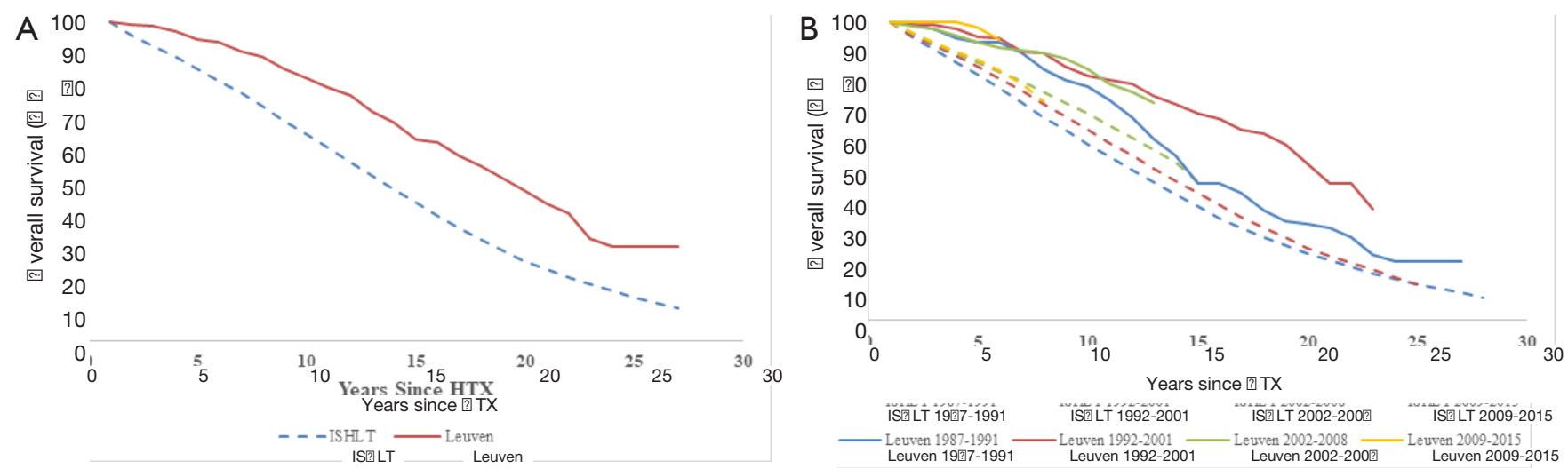

Figure 3 Conditional 1-year survival of heart recipients reported to ISHLT and recipients transplanted in Leuven. (A) All recipients. Leuven ( $\mathrm{n}=584$ ) versus ISHLT ( $\mathrm{n}=86,551)$ Chi Squared test $\mathrm{P}<0.001$ up to 27 years; (B) recipients by era: $1987-1991$ ( $\mathrm{n}=87)$ and $(\mathrm{n}=13,149)$ $\mathrm{P}<0.05$ up to 14 years; $1992-2001(\mathrm{n}=201)$ and $(\mathrm{n}=31,493) \mathrm{P}<0.01$ up to 23 years; 2002-2008 ( $\mathrm{n}=132)$ and ( $\mathrm{n}=21,130) \mathrm{P}<0.05$ up to 13 years; 2009-2015 ( $\mathrm{n}=164)$ and $(\mathrm{n}=20,779) \mathrm{P}<0.05$ up to 6 years. Chi Squared tests for differences in survival between ISHLT and Leuven per year. Log-rank test for survival in different eras in Leuven $\mathrm{P}<0.01$. HTX, heart transplant; ISHLT, International Society for Heart and Lung Transplantation.

probably never have been listed without their MCS, now become candidates. As they were once considered suitable candidates for implanting a MCS, the threshold to list them for transplantation reduces. Unless the results of long-term MCS improve and destination therapy can truly compete with transplantation, this evolution might negatively impact survival in the next decades.

Although impossible to prove, we strongly believe that the rigorous selection procedure we aimed for played an important role in our results.

Having an opt-out law, the number of donors per million inhabitants in Belgium is among the highest in the world (8-10). This results in shorter waiting times, for patients on the regular and the HU waitlist. A (very) short time on the HU waiting list was the only key to survival in the era before long-term MCS. Even nowadays it can be lifesaving for patient that is not a candidate for an MCS, such as those with hypertrophic cardiomyopathy or some complex forms of congenital heart disease and those needing a re-transplantation. As has been shown in several countries dealing with growing waitlists, a prolonged waiting time negatively impacts post-transplant survival (11). Many patients that were good candidates at the moment of listing, may turn out poor recipients 2 years later. Delisting patients that spanned their window of opportunity is extremely difficult. Pushed by increasing waiting times, we recently started discussing this possibility, at the moment of listing, especially when long waiting times are anticipated. The prolonged waiting time has another deleterious effect: it shifts patients from the regular to the HU waitlist, once their condition deteriorates. This is not a problem as long as the waiting time on the HU list is short. A long time on the HU list, however, is a recipe for bad results. The future transplant cardiologist will have the difficult task to be the gate keeper of his waitlist. When he or she allows too many patients on board, the boat might sink. As for our program, we are convinced that short waiting times, especially in the first 15 years of our program, have significantly contributed to our good survival results.

In contrast with the process of selecting a recipient, accepting or rejecting a donor is a fast-forward procedure. Initially, only young donors without vasopressors were accepted. Confronted with the growing number of patients on the waiting list and the decreasing number of donors (especially in Europe), most centers, including ours, progressively started accepting more marginal donor hearts (12-14). Nowadays, an ideal donor has become an exception and donors aged 60 years are no longer rejected automatically. Although the increase in donor age did not decrease our short-term survival, long-term survival might be negatively impacted. Time will tell.

Needless to say, the expertise and dedication of our surgeons played an important role in our survival results. This is indirectly suggested by the low rate of primary graft failure and the high 30-day survival. As the explantation 


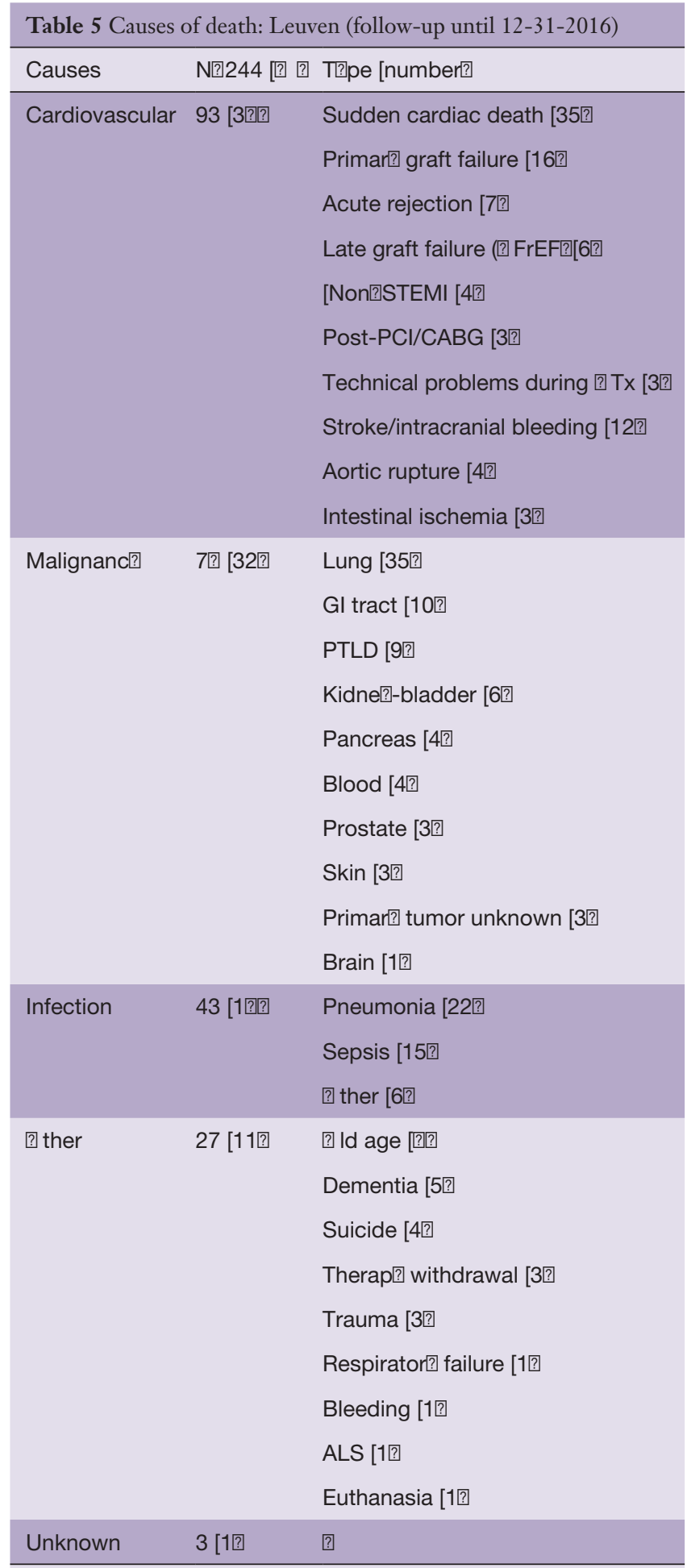

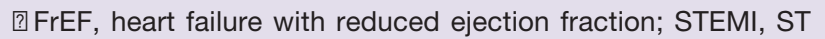

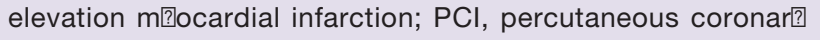
intervention; [CABG, [coronar?? [?

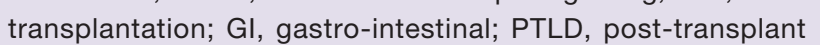

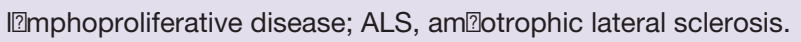

of the donor heart is performed by our own surgeons, the direct communication between the procurement and the implanting team might help to significantly reduce ischemic times (15-18). Also, most donors come from Belgian hospitals which results in short transportation times. Short transportation times may result in shorter ischemic intervals. In our analysis we, however, did not observe shorter ischemic times compared to ISHLT data.

Patients with complex congenital abnormalities and children are exclusively transplanted by surgeons that are used to performing congenital heart surgery. This can be considered to be a potential advantage.

In small countries such as Belgium it is not difficult to centralize follow-up. Obviously in the first postoperative year, when the risk of life threatening complications such as rejection and infection is highest, we think that presence of experienced transplant physicians can minimize the delay between the initiation of symptoms and the time of diagnosis and starting adequate treatment. It is difficult to prove that this system outperforms a more lenient followup, but we are convinced it does. Obviously, the advantage of a centralized follow-up stands or falls with the stability of the medical and paramedical teams involved. Even during long-term follow-up, when transplant recipients start to resemble general internal medicine patients, we think that having pathologists, microbiologists, hematologists, oncologists and other specialists with a large experience in transplant patients still implies an added benefit.

The effect of a well deployed social security system with a compulsory health insurance coverage, providing full reimbursement of immunosuppressive and other drugs, has not been studied extensively in heart recipients (19-22). It seems logical that these facilities, present in our country, decrease the risk of non-adherence and postponing medical help. They also might have contributed to our results, as was recently indirectly suggested in a large study comparing long-term graft kidney survival in Europe and the United States (22).

Patient education and medication adherence are two other important factors that might impact survival after transplantation. Since the beginning of our transplant program we have actively invested in these topics (23-27). This has not only resulted in scientific output, but has also likely lowered the threshold for patients to contact the transplant nurses and physicians in case of questions or problems. It may have also assisted in creating a culture where patients and their families form a team together with 
paramedics and physicians. The "Transplantoux"-project, a bi-annual biking and walking event organized for transplant recipients near the French Mont Ventoux, is a testament to this supportive cultural development (28). If nothing else, it temporarily stimulates a healthy lifestyle among the participants.

Finally, we pay a lot of attention to cardiovascular prevention and screening for malignancies. The significant and consistent decreases in age-adjusted cardiovascular mortality shown in European and US registries was attributed to better prevention and better treatment of cardiac disease (29). Although never investigated in heart recipients, we suppose that a healthy lifestyle and a low threshold for statin therapy and treatment of hypertension and diabetes will improve long-term survival after transplantation (30-32). The fact that a large number of our recipients had ischemic heart disease before the transplantation and the high percentage of recipients dying of cardiovascular causes enforces our belief. Considering the high prevalence of post-transplant smoking (more than $25 \%$ of heart recipients in a recent meta-analysis), patients' smoking status is systematically assessed at the out-patient visits and motivated recipients are referred to smoking cessation services (33).

Malignancies, particularly respiratory tumors, are a frequent cause of death $(34,35)$. Until recently, screening consisted of three monthly chest X-rays. Hoping to detect more cancers at a treatable stage, we shifted to an annual low-dose CT scan (36).

\section{Conclusions}

The relatively small number of heart transplantations performed worldwide and the impracticality of long-term follow-up studies explains the absence of large clinical trials trying to answer the question of how to obtain and maintain favorable results after heart transplantation. Even if these studies would have been performed, continuing changes in recipient and donor characteristics would reduce their relevance and hinder their translation into guidelines. Therefore, we can only speculate on factors that might explain our short- and long-term survival results. We focused on selection of potential candidates, obtaining informed consent, waiting time, ischemic time, centralized follow-up, health insurance coverage, patient education, medication adherence, cardiovascular prevention and screening for malignancies. Unfortunately, there is not such a thing as one master key to success. Many small keys however can contribute to a successful heart transplant program.

\section{Acknowledgements}

We sincerely thank Josef Stehlik (Chair ISHLT International Thoracic Transplant Registry Steering Committee) as well as Heather Neil, Aparna Sadavarte and Wida Cherikh from the UNOS Research Department (ISHLT Registry) for kindly providing us the ISHLT survival data and Ann Belmans for her statistical support. Special gratitude goes to Johan Vanhaecke and Wim Daenen, who founded the Leuven heart transplant program. Johan Vanhaecke initiated and personally maintained the database up to 2016. Finally, we thank the whole team, all recipients and their families and all donors and their families. Without their efforts and willingness, the exciting journey of heart transplantation would never have been possible.

\section{Footnote}

Conflicts of Interest: The authors have no conflicts of interest to declare.

\section{References}

1. Taylor DO, Stehlik J, Edwards LB, et al. Registry of the International Society for Heart and Lung Transplantation: twenty-sixth official adult heart transplant teport-2009. J Heart Lung Transplant 2009;28:1007-22.

2. Lund LH, Edwards LB, Dipchand AI, et al. Registry of the International Society for Heart and Lung Transplantation: 33th official adult heart transplant report-2016; Focus theme: primary diagnostic indications for transplant. J Heart Lung Transplant 2016;35:1158-69.

3. Weiss ES, Allen JG, Kilic A, et al. Development of a quantitative donor risk index to predict short-term mortality in orthotopic heart transplantation. J Heart Lung Transplant 2012;31:266-73.

4. Weiss ES, Allen JG, Arnaoutakis GJ, et al. Creation of a quantitative recipient risk index for Mortality Prediction After Cardiac Transplantation (IMPACT) Ann. Thorac Surg 2011;92:914-21.

5. Kilic A, Allen JG, Weiss ES. Validation of the United States-derived Index for Mortality Prediction After Cardiac Transplantation (IMPACT) using international registry data. J Heart Lung Transplant 2013;32:492-98. 
6. Mehra MR, Kobashigawa J, Starling R, et al. Listing criteria for heart transplantation: International Society for Heart and Lung Transplantation Guidelines for the care of cardiac transplant candidates. J Heart Lung Transplant 2006;25:1024-42.

7. Mehra MR, Canter CE, Hannan MM, et al. The 2016 International Society for Heart Lung Transplantation listing criteria for heart transplantation: a 10-year update. J Heart Lung Transplant 2016;35:1-23.

8. Shafran D, Kodish E, Tzakis A. Organ Shortage: the greatest challenge facing transplant medicine. World J Surg 2014;38:1650-7.

9. Ugur ZB. Does presumed consent save lives? Evidence from Europe. Health Econ.2015;24:1560-72.

10. Roels L, Rahmel A. The European experience. Transpl Int 2011;24:350-67.

11. Goldstein BA, Thomas L, Zaroff JG, et al. Assessment of heart transplant waitlist time and pre- and posttransplant failure: a mixed methods approach. Epidemiology 2016;27:469-76.

12. Gaffey AC, Cucchiara AJ, Goldberg LR, et al. Transplantation of Center for Disease Control "HighRisk" donor hearts does not adversely impact long-term outcomes in adults. J Card Fail 2016;22:376-82.

13. Fudim M, Davis ME, Jenkins C, et al. Marginal Donor Use in Patients Undergoing Heart Transplantation With Left Ventricular Assist Device Explantation. Ann Thorac Surg 2015;100:2117-25; discussion 2125-6.

14. Kilic A, Weiss ES, Allen JG, et al. Should orthotopic heart transplantation using marginal donors be limited to higher volume centers. Ann Thorac Surg 2012;94:695-702.

15. Yeen W, Polgar A, Guglin M, et al. Outcomes of adult orthotopic heart transplantation with extended allograft ischemic time. Transplant Proc 2013;45:2399-405.

16. Banner NR, Thomas HL, Curnow E, et al. The importance of cold and warm ischemia for survival after heart transplantation. Transplantation 2008;86:542-7.

17. Del Rizzo DF, Menkis AH, Pflugfelder PW, et al. The role of donor age and ischemic time on survival following orthotopic heart transplantation. J Heart Lung Transplant 1999;18:310-9.

18. Pflugfelder PW, Thomson D, Singh NR, et al. Cardiac allograft ischemic time. Relation to graft survival and cardiac function. Circulation 1989;80:III116-21.

19. Sommers BD, Gawande AA, Baicker K. Health insurance coverage and health: what recent evidence tells us. N Engl J Med 2017;377:586-93.

20. Tumin D, Foraker RE, Smith S, et al. Health insurance trajectories and long-term survival after heart transplantation. Circ Cardiovasc Qual Outcomes 2016;9:576-84.

21. Allen JG, Weiss ES, Amaoutakis GJ, et al. Insurance and education predict long-term survival after orthotopic heart transplantation in the United States. J Heart Lung Transplant 2012;31:52-60.

22. Gondos A, Döhler B, Brenner H, et al. Kidney graft survival in Europe and the United States: strikingly different long-term outcomes. Transplantation 2013;95:267-74.

23. Dobbels F, De Bleser L, Berben L, et al. Efficacy of a medication adherence enhancing intervention in transplantation. J Heart Lung Transplant 2017;36:499-508.

24. Cajita MI, Denhaerynck K, Dobbels F, et al. Health literacy in heart transplantation: prevalence, correlates and associations with health behaviors- findings from the international BRIGHT study. J Heart Lung Transplant 2017;36:272-9.

25. De Bleser L, Matteson M, Dobbels F, et al. Interventions to improve medication-adherence after transplantation: a systematic review. Transpl Int 2009;22:780-97.

26. Dobbels F, De Geest S, Van Cleemput J, et al. Effect of late medication non-compliance on outcome after heart transplantation: a 5-year follow-up. J Heart Lung Transplant 2004;23:1245-51.

27. Dobbels F, De Geest S, Martin S, et al. Prevalence and correlates of depression symptoms at 10 years after heart transplantation: continuous attention required. Transpl Int 2004;17:424-31.

28. Available online: http://www.transplantoux.be

29. Moran AE, Forouzanfar MH, Roth GA, et al. Temporal trends in ischemic heart disease mortality in 21 world regions, 1980 to 2010: the global burden of disease 2010 study. Circulation 2014;129:1483-92.

30. Cholesterol Treatment Trialists' (CTT) Collaborators, Mihaylova B, Emberson J, et al. The effects of lowering LDL cholesterol with statin therapy in people at low risk of vascular disease: meta-analysis of individual data from 27 randomised trials. Lancet 2012;380:581-90.

31. Cholesterol Treatment Trialists' (CTT) Collaboration, Baigent C, Blackwell L, et al. Efficacy and safety of more intensive lowering of LDL cholesterol: a meta-analysis of data from 170,000 participants in 26 randomised trials. Lancet 2010;376:1670-81.

32. Blood Pressure Lowering Treatment Trialists' Collaboration. Blood pressure-lowering treatment based on cardiovascular risk: a meta-analysis of individual patient 
data. Lancet 2014;384:591-8.

33. Duerinckx N, Burkhalter H, Engberg SJ, et al. B-Serious consortium. Correlates and outcomes of posttransplant smoking in solid organ transplant recipients: a systematic literature review and meta-analysis .Transplantation 2016;100:2252-63.

34. Van Keer J, Droogné W, Van Cleemput J, et al. Cancer after heart transplantation: a 25 -year single center perspective. Transplant Proc 2016;48:2172-7.

35. Dantal J, Campone M. Daunting but worthy goal: reducing de novo cancer incidence after transplantation. Transplantation 2016;100:2569-83.

36. National Lung Screening Trial Research Team, Aberle DR, Adams AM, et al. Reduced lung-cancer mortality with low-dose computed tomographic screening. N Engl J Med 2011;365:395-409.

Cite this article as: Van Cleemput JJ, Verbelen TO, Van Aelst LN, Rega FR. How to obtain and maintain favorable results after heart transplantation: keys to success? Ann Cardiothorac Surg 2018;7(1):106-117. doi: 10.21037/acs.2017.12.03 
Table S1 Baseline characteristics of recipients and donors: ISHLT

\begin{tabular}{|c|c|c|c|c|c|c|}
\hline Eras & 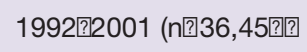 & Pףalue & 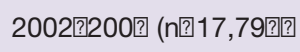 & $\mathrm{P}$ 冈alue & 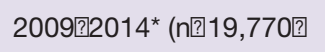 & Pףalue \\
\hline 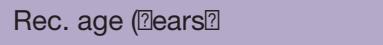 & 51.4 ?⒒0 & NS & 51.1012 .4 & -30.05 & 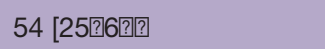 & 0.0001 \\
\hline 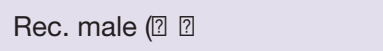 & 20.0 & NS & 77.3 & NS & 74.9 & NS \\
\hline 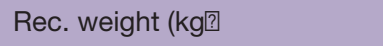 & 76.0묵14.5 & ?? 0.0001 & 7?ㄱ.?이 15.5 & ? 0.0001 & 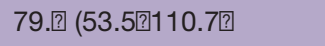 & 20.0001 \\
\hline Rec.Theight和m[ & 172.7즘․7 & 国0.001 & 172.9ำ?.9 & NS & 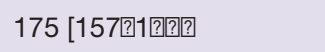 & 0.001 \\
\hline 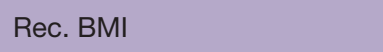 & 25.3? 4.1 & ?0.0001 & 26.0 무 4.3 & ? 0.0001 & 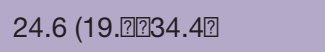 & NS \\
\hline Rec.æreatinine凤mg/dL? & $1.3 \sqrt{0} 0.5$ & 2]0.0001 & 1.320 .5 & NS? & 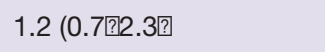 & ? 0.05 \\
\hline 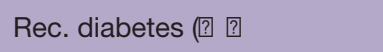 & 13.1 & NS & 22.0 & 0.001 & 25.9 & 0.0001 \\
\hline 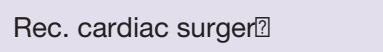 & NA & NA & 40.0죽 & 0.001 & 49.6 & ใ0.0001 \\
\hline Rec.ædiagnosis & & 国0.001 & & ? 0.0001 & & 0.0001 \\
\hline 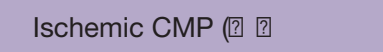 & 45.2 & NS & 39.5 & NS? & 35.1 & NS? \\
\hline Idiopathic ХCMP每? ] & 45.9 & ? 0.05 & 49.5 & จㅇ.0.05 & 55.6 & 20.005 \\
\hline 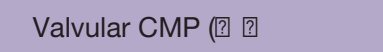 & 3.2 & 2]0.05 & 2.4 & 0.005 & 2.? & NS \\
\hline Re-transplant的] 圆 & 1.9 & 0.005 & 2.3 & 20.05 & 2.? & 0.001 \\
\hline 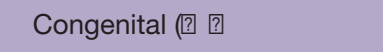 & 1.? & NS & 2.4 & 0.001 & 3.3 & 0.005 \\
\hline ? thera]? & 1.9 & NS & 3.? & NS & 0.6 & 0.0001 \\
\hline ? ospitali?ed & 5 回.6 & 0.0001 & 46.5 & 0.0001 & 43. 우 & 0.0001 \\
\hline ivতึ̄notropes & 4回.9 & ?ำ.0001 & 44.? & ?0.0001 & 39.9 & 20.0001 \\
\hline Ventilator & 3.1 & NS? & 2.9 & NS? & 2.3 & ?20.05 \\
\hline iABP & 6.? & 0.001 & 6.9 & 0.005 & 6.2 & 0.001 \\
\hline ECM? & 0.3 & NS & 0.7 & NS? & 1.2 & NS \\
\hline LVAD & 4.1 & NS?] & 19.0 & NS & 36.6 & NS \\
\hline RVAD & 0.1 & ?? 0.0001 & 2.9 & NS? & 3.2 & NS? \\
\hline TA? & 0.4 & NS & 0.4 & NS & 1.4 & NS \\
\hline 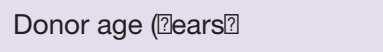 & 32.3?1․? & NS & 33.6? 13.0 & ?20.05 & 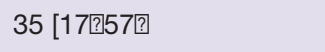 & 20.0001 \\
\hline 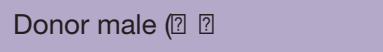 & 67.? & NS & 69.5 & NS & 6미.2 & NS \\
\hline 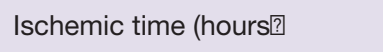 & 2.5 国 1.4 & ?30.05 & 2. 지맘 1.5 & 0.001 & 3.3圂1.6回5.1回 & NS \\
\hline 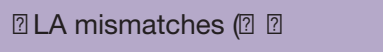 & & 20.01 & & NS & & NS \\
\hline 0?2 & 4.? & & 4.3 & & 3.? & \\
\hline 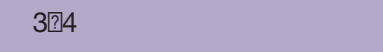 & 41.5 & & 40.5 & & 3] .4 & \\
\hline 50 & 53.7 & & 55.2 & & 57.? & \\
\hline 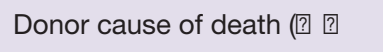 & & ?]0.0001 & & NS & & NS \\
\hline ?] eadThrauma & 45.2 & & 52.1 & & 42.9 & \\
\hline Stroke & 2 ?].? & & 29.6 & & 23.2 & \\
\hline ? ther & 26.5 & & 10.3 & & 33.9 & \\
\hline 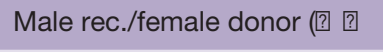 & 20.7回 & NS & 17.3쥬 & NS & 16.6 & NS \\
\hline Female[rec./male[donori] [] & 9.2? & NS & 10.1串 & NS & 9.? & NS \\
\hline
\end{tabular}

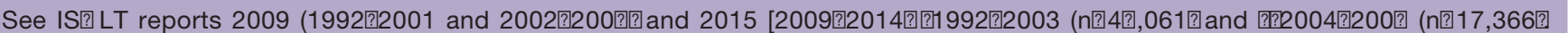

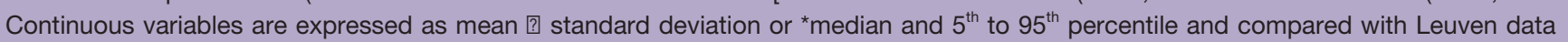

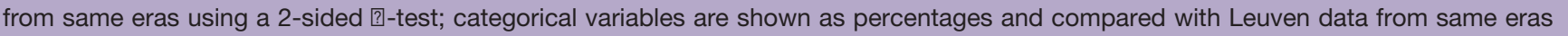

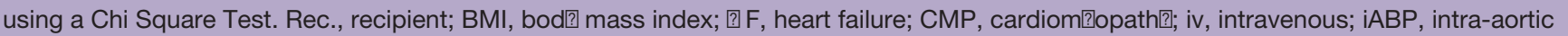

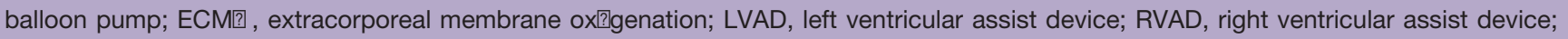
TA? , [7otal[? 


\begin{tabular}{|c|c|c|c|}
\hline Year & 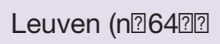 & IS? LTTZ्वn? 109,426? & $\mathrm{P}$ value \\
\hline 0 & 100.0?0.0 & 100.0?0.0 & \\
\hline 1 & 91.9?1.1 & ?2.1?0.1 & ? 0.0001 \\
\hline 2 & 91.1?1.2 & 7?.6?ำ.1 & ? 0.0001 \\
\hline 3 & 90.7?1.2 & 75.?ำ? 0.1 & ? 0.0001 \\
\hline 4 & ใ?9.0? 1.3 & 72.9?30.1 & ? 0.0001 \\
\hline 5 & ?7.0? 1.4 & 70.0?0.1 & ? 0.0001 \\
\hline 6 & ใ6.1?1.5 & 66.9? 0.2 & ? 0.0001 \\
\hline 7 & ?3.3? 1.6 & 63.6? 0.2 & ? 0.0001 \\
\hline ?? & ?1.7?1.7 & 60.1?0.2 & ? 0.0001 \\
\hline 9 & 7?.3? 1.9 & 56.6? 0.2 & ? 0.0001 \\
\hline 10 & 75.5??2.0 & 53.2? 0.2 & ? 0.0001 \\
\hline 11 & 73.1囵.1 & 49.5?0.2 & ?]0.0001 \\
\hline 12 & 70.5 ㄱ.?2.2 & 45.9?30.2 & ? 0.0001 \\
\hline 13 & 66.0??2.3 & 42.4? 0.2 & ? 0.0001 \\
\hline 14 & 62.지?2.4 & 39.0?0.2 & ใ0.0001 \\
\hline 15 & 5?.0ㄱ. 2.6 & 35.4园0.2 & ? 0.0001 \\
\hline 16 & 56.9?2.6 & $31.9 ? 0.2$ & ? 0.0001 \\
\hline 17 & 53.5?2.7 & 2?․ㄹㅁำ 0.2 & ? 0.0001 \\
\hline 10 & 50.2??2.? & 25.9?0.2 & ? 0.0001 \\
\hline 19 & 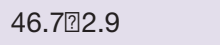 & 23.1匀 & ? 0.0001 \\
\hline 20 & 43.2??3.0 & 20.5? 0.2 & ? 0.0001 \\
\hline 21 & 39.3?3.1 & 1?.320.2 & ?0.0001 \\
\hline 22 & 36.7궁.3 & 16.2? 0.2 & 20.0001 \\
\hline 23 & 29.4무3.6 & 14.4뭉.2 & ?0.0001 \\
\hline 24 & 26.9?3.7 & 12.6? 0.2 & ? 0.001 \\
\hline 25 & 26.9?3.7 & 11.0?0.2 & ? 0.0001 \\
\hline 26 & 26.9?3.7 & 9.6무0.2 & ?0.0001 \\
\hline 27 & 26.9?3.7 & ใ. & ? 0.0001 \\
\hline 2]?] & ? & 6.9 ?ㅇ․ 0.3 & ? \\
\hline 29 & ? & 5.4? 0.4 & ? \\
\hline
\end{tabular}

\begin{tabular}{|c|c|c|c|}
\hline Year & 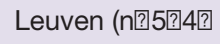 & IS? LTTत्(n?] 6,551? & P风alue \\
\hline 10? & 100.0?0.0 & 100.0?0.0 & \\
\hline 2 & 99.120 .4 & 95.?ำ0.1 & ? 0.0001 \\
\hline 3 & 9?.7?웅.5 & 92.3?0.1 & ?0.0001 \\
\hline 4 & 96.?ㅁำ0.? & ?ㄱ.9?ㅇ.? 0.1 & ? 0.0001 \\
\hline 5 & $94.6 ? 1.0$ & ?ㄷ.3?0.1 & ?20.0001 \\
\hline 6 & 93.7? 1.1 & ? 1.5 ? 0.1 & ? 0.0001 \\
\hline 7 & $90.6 ? 1.4$ & 77.5?ㅇ‥2 & ? 0.0001 \\
\hline 圆 & ?ำ.?ำ1.5 & 73.3?0.2 & ? 0.0001 \\
\hline 9 & ใ?5.2??1.7 & 69.0?0.2 & ? 0.0001 \\
\hline 10 & ?2.1?1.9 & 64.?ำ0.2 & ? 0.0001 \\
\hline 11 & 79.5??2.0 & 60.3?0.2 & ? 0.0001 \\
\hline 12 & 76.7무2.2 & $56.0 ? 0.2$ & ?20.0001 \\
\hline 13 & 71.?ำ2.4 & 51.6?ำ.2 & ? 0.0001 \\
\hline 14 & 6?.3?2.5 & 47.5?0.2 & ? 0.0001 \\
\hline 15 & 63.1 目2.7 & [443.1?0.2 & 0.0001 \\
\hline 16 & 61.9 ?2.7 & 3?.9?ำ.2 & ? 0.0001 \\
\hline 17 & 50․1团2.9 & 35.1 目 0.2 & 0.0001 \\
\hline 1 回 & 54.6?3.0 & $31.6 ? 0.2$ & 0.0001 \\
\hline 19 & 50.?ำ3.1 & 2ใ.2?ำ.2 & ? 0.0001 \\
\hline 20 & 47.0?3.2 & 25.0 ? 0.2 & ? 0.0001 \\
\hline 21 & 42.7?3.4 & 22.3?0.2 & ?20.0001 \\
\hline 22 & 39.9?3.5 & 19.ㄱำ0.2 & ? 0.0001 \\
\hline 23 & 32.0?3.9 & 17.6?ำ.3 & ?20.001 \\
\hline 24 & $29.2 ? 4.0$ & 15.4?0.3 & ?ㅇ․ 0.001 \\
\hline 25 & $29.2 ? 4.0$ & 13.4?0.3 & ?20.0001 \\
\hline 26 & $29.2 ? 4.0$ & 11.7匄0.3 & 0.0001 \\
\hline 27 & $29.2 ? 4.0$ & 10.3?0.3 & ?20.0001 \\
\hline 2?] & ? & ?․4? 0.3 & 目 \\
\hline 29 & ? & 6.5?0.4 & ?] \\
\hline
\end{tabular}




\begin{tabular}{|c|c|c|c|}
\hline Year & Leuven行n?100? & IS? LTT/Zn? 17,173? & P®alue \\
\hline 0 & 100.0?0.00 & 100.0? 0.0 & \\
\hline 1回 & 워.7궁.1 & 7?.2? 0.3 & 0.0002 \\
\hline 2 & 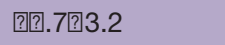 & 74.2?0.3 & ? 0.0001 \\
\hline 3 & ใ7.6?3.3 & 71.0?0.4 & ? 0.0001 \\
\hline 4 & ใ4.5?3.7 & 67.7?ㅇ․ 0.4 & ? 0.0001 \\
\hline 5 & ใ3.5?3.? & 64.4무 0.4 & ? 0.0001 \\
\hline 6 & 궁.5?3.?ำ & 60.ㄱำ0.4 & ? 0.0001 \\
\hline 7 & ใ0.4? 4.0 & 57.0 ? 0.4 & ? 0.0001 \\
\hline ? & 75.3? 4.4 & 53.2? 0.4 & ??0.0001 \\
\hline 9 & 72.2? 4.6 & 49.제? 0.4 & ? 0.0001 \\
\hline 10 & 70.1 ? 4.7 & 46.2? 0.4 & ??0.0001 \\
\hline 11 & 66.0? 4.? & 42.게? 0.4 & ? 0.0001 \\
\hline 12 & 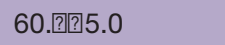 & 39.3? 0.4 & ? 0.0001 \\
\hline 13 & $54.6 ? 5.1$ & 36.1 目 0.4 & 0.001 \\
\hline 14 & 49.5?ㄷ.1 & [B33.0?0.4 0.4 & ? 0.01 \\
\hline 15 & 41.2? 5.0 & 30.0?0.4 & ?0.05 \\
\hline 16 & 41.2? 5.0 & 26.?ำ? 0.4 & 2]0.01 \\
\hline 17 & 3?․1ㄴ? 4.9 & 24.3?0.4 & ? 0.01 \\
\hline 1 ?] & 33.0? 4.? & 21.제? 0.3 & ? 0.05 \\
\hline 19 & 29.9 ? 4.7 & 19.5?0.3 & ?20.05 \\
\hline 20 & 2??.94.6 & 17.5目0.3 & ? 0.05 \\
\hline 21 & 27.?ำ 4.6 & 15.?ำ0.3 & ? 0.01 \\
\hline 22 & 24.7? 4.4 & 14.0? 0.3 & ? 0.05 \\
\hline 23 & 19.6? 4.0 & 12.4?0.3 & NS \\
\hline 24 & 17.5무3.9 & 11.0?이 & NS \\
\hline 25 & 17.5?3.9 & 9.6? 0.3 & ? 0.05 \\
\hline 26 & 17.5무3.9 & 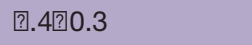 & ? 0.05 \\
\hline 27 & 17.5?3.9 & 7.4ใด 0.3 & ? 0.01 \\
\hline 2?] & ? & 6.0?으.3? & ? \\
\hline 29 & ? & 4.7?0.3 & ? \\
\hline
\end{tabular}

\begin{tabular}{|c|c|c|c|}
\hline Year & 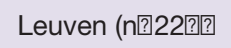 & IS? LTT/n?36,45?]? & Pףialue \\
\hline 0 & 100.0?ㅇ.? & 100.0回0.0 & \\
\hline $1 ?$ & 90.?ำ2.0 & ? 0.9 ?? 0.2 & ? 0.0001 \\
\hline 2 & [?9.9?2 2.1 & 77.3? 0.2 & ? 0.0001 \\
\hline 3 & [99.9?2.1 & 74.5ㅁำ.2 & ? 0.0001 \\
\hline 4 & ใ?].5ำ2.2 & 71.7?0.2 & ? 0.0001 \\
\hline 5 & ?76.2?2.3 & 6?․7ㅁำ0.2 & ใ? 0.0001 \\
\hline 6 & [9.7주2.4 & 65.6?ㅇ‥2 & ? 0.0001 \\
\hline 7 & ใ?1.6?⒉6 & 62.2??0.3 & ? 0.0001 \\
\hline ?] & ?1.1园2.7 & 5?․7뭉.3 & ??0.0001 \\
\hline 9 & 77.0ㅁํ2.9 & 55.2? 0.3 & ? 0.0001 \\
\hline 10 & 74.2??3.0 & 51.7무0.3 & ใ? 0.0001 \\
\hline 11 & 73.3구3.0 & 4?․1의 0.3 & ใ? 0.0001 \\
\hline 12 & 71.9?궁.1 & 44.6?? 0.3 & ใ? 0.0001 \\
\hline 13 & 6?․2?ㄱ.? & 41.1目0.3 & ? 0.0001 \\
\hline 14 & 65.9무3.2 & 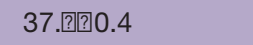 & ?ㄱ.0.0001 \\
\hline 15 & 63.0구3.3 & 34.4 ?‥4 & ? 0.0001 \\
\hline 16 & 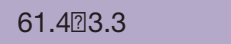 & 31.2 ?? 0.4 & ใ? 0.0001 \\
\hline 17 & 5?․1중.5 & 2?.1ج0.4 & ? 0.0001 \\
\hline 1 ] & 56.6ㅁ?3.5 & 25.2? 0.3 & ? 0.0001 \\
\hline 19 & 53.3?ㄱ.? & 22.4 ? 0.3 & ? 0.0001 \\
\hline 20 & 47.9주4.0 & 19.7目0.3 & ? 0.0001 \\
\hline 21 & 41.6?ㄴ.4 & 17.5?0.3 & ? 0.0001 \\
\hline 22 & 41.6주4.4 & 15.6?ำ.3 & ? 0.0001 \\
\hline 23 & $33.9 ? 6.1$ & 13.9?0.3 & ?0.05 \\
\hline 24 & ? & 11.6무0.3 & ? \\
\hline 25 & ? & 9.ㄹำ 0.5 & ? \\
\hline
\end{tabular}




\begin{tabular}{|c|c|c|c|}
\hline Year & Leuven闻司141? & 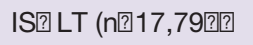 & Pॠalue \\
\hline 0 & 100.0 ?]0.00 & 100.0?0.0 & \\
\hline 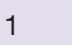 & 94.0?2.1 & ใ3.4? 0.2 & ? 0.0001 \\
\hline 2 & 92.5지 2.3 & ใด.2?0.3 & ?]0.0001 \\
\hline 3 & 91.ㅈ? 2.4 & 77.5?0.3 & ?20.0001 \\
\hline 4 & ใ?9.6?2. 2.6 & 74.?ㅁำ0.3 & ?]0.0001 \\
\hline 5 & ใ7.3?2.9 & 72.1?0.3 & ?0.0001 \\
\hline 6 & ใ25.?주3.0 & 69.4?0.3 & ? 0.0001 \\
\hline 7 & ?5.1?3.1 & 66.7?0.3 & ?]0.0001 \\
\hline ?? & 204.3?3.1 & 63.ㄱำ 0.3 & ??0.0001 \\
\hline 9 & ?2.4궁.4 & 60.7?0.3 & ?20.0001 \\
\hline 10 & 7?․9?3.?ำ & 57.6?ำ.3 & ?]0.0001 \\
\hline 11 & 74.3 ? 4.4 & 54.2?0.4 & ?0.0001 \\
\hline 12 & 72.0? 4.? & 51.1?0.4 & ? 0.0001 \\
\hline 13 & 6?.6? 5.7 & 47.5? 0.4 & ?0.001 \\
\hline 14 & 囼 & [2444.1?0.5 & ? \\
\hline 15 & ? & 3?.7? 0.9 & ? \\
\hline
\end{tabular}

\begin{tabular}{|c|c|c|c|}
\hline Year & 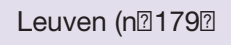 & IS? LT圆n? 19,770? & Pףalue \\
\hline 0 & 100.0? 0.00 & 100.0?0.0 & \\
\hline 1 圆 & 93.2?2.0 & ?75.0?0.2 & ? 0.0001 \\
\hline 2 & 93.2?2.0 & 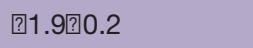 & ? 0.0001 \\
\hline 3 & 93.2?2.0 & 79.2?0.3 & ? 0.0001 \\
\hline 4 & 93.2?2.0 & 76.6? 0.3 & ?0.0001 \\
\hline 5 & 91.3?2.7 & 74.0? 0.3 & 0.0001 \\
\hline 6 & ?7.6?34.4 & 71.1 ?0.4 & ?0.001 \\
\hline 7 & ? & 67.5? 0.5 & ? \\
\hline ?] & ? & 62.3?ㅇ.? & ? \\
\hline
\end{tabular}

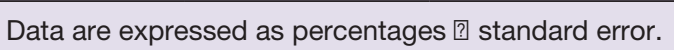

